\title{
RELIGIÃO, GÊNERO E TERRITÓRIO: DISCURSOS MIDIÁTICOS DA PARADA GAY DE SÃO PAULO
}

- NILTON ABRANCHES JUNIOR'

- ARTHUR MARQUES DE ALMEIDA NETO²

Resumo: A Parada Gay de São Paula se caracteriza como senda um espaço de atividade política GLBT brasileira, reunindo participantes de todas as partes do país, geranda visibilidade mediática com repercussão mundial. 0 presente trabalho tem camo objetivo discutir a performance da atriz transexual Viviany Belebani durante a edição do evento de 28 de junho de 2015 e a sua conseqüente reverberaçãa no espaça mediático. Fundamenta essa discussão a teoria Corpomídia de Katz e Greiner (2005) e a teoria do Merme de Dawkins (200I), para relacionar a ressanância de informações e sua percepção pelo corpo. A relação das duas teorias aponta para um aspecto político: a transfarmaçãa da informaçãa EM corpo, desde quanda ele é entendida como mídia e discursa. Percebe-se que o corpomídia transexual é um discurso imagético de resistência contra ações hegemônicas de caráter homofóbica, respaldadas pela ausência de legislação específica que normatizem esses atos de violências enquanto crime.

Palavras-chaves: Religião. Cênero. Coгpomídia. Meme, Território.

\section{Introdução}

O fenômeno do fluxo de informações exige modos de entendimento que, na atualidade, implica em abordagens que conectam campos ou áreas de conhecimento diversas. Invoca-se, dessa forma, como muitos autores já o fizeram, a necessidade de compor quadros teóricos específicos para lidar com determinados objetos. Bastide (1959: 55, apud Pinheiro, 2009: 20), exemplifica a importância dessa compreensão, através do trabalho do sociólogo que lida com o o contexto brasileiro: 
O sociólogo que estuda o Brasil não sabe mais que sistema de conceitos utilizar. Todas as noções que aprendeu nos países europeus e norteamericanos não valem aqui. [...] Seria necessário, em lugar de conceitos rígidos, descobrir noções de certo modo líquidas, capazes de descrever fenômenos de fusão, de ebulição, de interpenetração; noções que se modelariam conforme uma realidade viva, em perpétua transformação.

$\mathrm{Na}$ esteira desse pensamento, convoca-se um arcabouço conceitual que busca dar conta de um fenômeno vivo, real, onde a transformação é uma condição de existência de qualquer sistema e rede viva, e um substantivo aqui usado como sinônimo para o termo evolução. Propõe-se que o corpo é foco central do fenômeno comunicacional.

O campo de conhecimento da Geografia já apresenta diversos estudos que discorrem sobre teorias do corpo, a exemplo dos trabalhos de Brito-Henriques (2009) que trazem uma abordagem do corpo, por exemplo, aproximando com relações de poder.

Apesar dessas diferentes contribuições, a proposta deste trabalho é trazer uma discussão que conecta conhecimentos em Geografia com
Comunicação. Essa dialógica se pretende firmar em uma perspectiva indisciplinar. Katz (2004, apud Katz e Greiner, 2005: 126), explica que "para tratar do corpo, não basta o esforço de colar conhecimentos buscados em disciplinas aqui e ali. Nem trans nem interdisciplinarmente se mostram estratégias competentes para a tarefa”.

Logo, a invocação que se faz é um estudo que propõe o corpo como matriz da comunicação e realidade viva em constante evolução, em especial, no que diz respeito à condição de estar sempre EM fluxos de informações. Isso remete ao que Katz e Greiner (2005: 130) explicam:

\begin{abstract}
As relações entre o corpo e o ambiente se dão por processos coevolutivos que produzem uma rede de pré-disposições perceptuais, motoras, de aprendizado e emocionais. Embora o corpo e ambiente estejam envolvidos em fluxos permanentes de informação, há uma taxa de preservação que garante a unidade e sobrevivência dos organismos e de cada ser vivo em meio à transformação constante que caracteriza os sistemas vivos.
\end{abstract}

Assume-se que o corpo, como centro do processo comunicativo, está sempre na situação de transformação, tanto por razões evolutivas quanto pela 
interação com os fluxos de informação. Sobre a veiculação das informações e a questão da velocidade implicada nesse processo, importante se faz a perspectiva de que novos caminhos precisam ser abertos para a ampliação do olhar na direção da compreensão de uma situação global, mas que envolve desinências específicas em cada contexto. Ou seja, "não se pode, portanto, de repente, em nome do contemporâneo, falar de velocidade ou mobilidade globalizantes sem se levar em conta o lugar onde a tomada está ligada" (Martín-Barbeiro, 2002, apud Pinheiro, 2009: 13).

Nesse viés, é preciso levar em conta que os lugares - ou locais - têm especificidades (que se distinguem, por exemplo, pelo modo de acesso à informação difundida em rede, velocidades de acesso às informações, culturas diversas, entre outros), apesar da grande enxurrada de pontos de conexão e interação existentes, mas que estes mesmos lugares podem estar ou não sujeitos.

Vale refletir sobre as especificidades dos locais e as diferentes compreensões sobre as informações que são difundidas em rede - tanto a forma e condição do acesso na atualidade quanto a própria percepção dessas informações. Nessa reflexão, considera-se que "o local talvez tenha que ser entendido de alguma forma como interdependente do global; globalização talvez sempre envolva localização. Assim, é dado a nós o neologismo 'glocalização”' (BAUCHSPIES at al., 2006: 100, tradução nossa) $)^{2}$.

Parte-se ainda do pressuposto de que os espaços transformam-se em territórios a partir de ações políticas (Becker, 1983). A partir de territorialidades momentâneas, decorrente da frequência de movimentos sociais realizados no espaço, o território é produzido. Sendo assim, pode se constituir em múltiplos e variáveis, resultado das diferentes relações de poder existentes no mesmo recorte especial (Saquet, 2007). Durante o ato politico reconhecido como a "Parada Gay" de São Paulo, a Avenida Paulista, recorte espacial objeto deste estudo, transforma-se em território singular a partir da apropriação daquele espaço por um grupo específico de indivíduos, exercendo sua territorialidade.

\section{Informação e mídias: $O$ glocal, o corpomídia e os memes}

Para Eugênio Trivinho (2012: 13), o glocal, como fenômeno, não se resume mais ao global ou ao local. O fenômeno glocal, “[ ...] vale dizer, nem global, nem 
local, antes processo de terceira grandeza, não redutível aos seus dois fatores constitutivos, e há décadas realizado" (Trivinho, 2012: 13), refere-se à condição onde o corpo está localizado (em um lugar específico), mas conectado globalmente por dispositivos que acessam redes de informações, notadamente, a internet.

O termo é desinência híbrida de um processo há décadas realizado, que “[ ...] reescalona para o território planetário e potencializa ao infinito o fenômeno dessa hibridação de 'planos' de existência, experiência e atuação”, onde o mundo pode ser considerado um “ $[\ldots]$ caleidoscópio de redutos glocais entrecruzados de e para a circulação de informações" (id.).

Trivinho (2012) apresenta como o conceito glocal teve origem no mundo corporativo japonês, na década de 1980 . Tornou-se uma palavra conjuminada dos termos global e local para a compreensão do modus operandi fundamental $\mathrm{da}$ civilização mediática ${ }^{3}$. O termo foi incorporado nas ciências humanas e sociais primeiramente pelo sociólogo britânico Roland Robertson, cuja preocupação com os hibridismos era o de acentuar o relativismo dos usos na linguagem de categorias dicotômicas ou bipolares e aparentemente opostas (global e local, público e privado, próximo e distante, coletivo e individual, externo e interno etc.), assinalando para a emergência social-histórica dos fenômenos híbridos.

Trivinho (2012) apresenta a diferenciação stricto sensu e lato sensu do termo. Segundo o autor, a versão lato sensu é “[ [...] aberta, não tecnológica, isto é, não dependente de máquinas capazes de rede ou de tempo real”. Em outras palavras, a configuração lato sensu é constatada em “[...] contextos presenciais não mediados pelo tempo real toda vez que o objeto da conversação entre interlocutores corresponde a temas (centrais ou secundários) da agenda mediática (corrente ou pregressa)" (Trivinho, 2012: 160, nota 20). Em sua acepção stricto sensu, o termo é formado “[ $\ldots]$ por cinco fatores fundamentais: media, tempo real, fluxo sígnico, sujeito/agente (de recepção/ acesso/retransmissão) e acoplamento entre subjetividade/corpo e tecnologia/rede" (ibid.). Ambas as acepções interessam para a presente discussão.

A situação da humanidade, na atualidade, mesmo em lugares distantes ou desconectados em rede, impele à compreensão da proposição de um contexto glocal. Ele se trata de um contexto que 
[... encerra o reduto de acesso/recepção/transmissão/irradiaç ão comunicativa (massificado ou interativo, coletivo ou individual, sedentário ou nômade) onde o corpo próprio se encontra (em contato com equipamento capaz de rede) e no qual e/ou a partir do qual a consciência individual refaz o mundo para si e, em geral, atua a partir dos signos de interação correntes. (Trivinho, 2012: 14).

O contexto glocal é algo que precisa ser considerado, em principal, assumindo a postura de compreender a (ainda) existência desses lugares de especificidades múltiplas. Contextos diversos, culturas diversas: modos diferentes de se ver o mundo, apesar da situação glocal que avança a passos largos. Assim, O processo de glocalização projeta a experiência cotidiana e a própria existência para uma realidade planetária.

Glocalizado - em condição glocal - o indivíduo experimenta uma situação em que o corpo está em trânsito direto com as informações, sem sair do seu lugar; está sujeito, mas não passivo, às conexões múltiplas informacionais e ao bombardeio de dados, quando em contato com um equipamento (hardware, seja ele, por exemplo, um computador, um notebook, um smartphone, um tablet, uma smart TV, entre outros) capaz de acessar uma rede. Essa condição glocal pode ser compreendida como um

[...] modus vivendi para a maioria dos países existentes $[\ldots]$, característica tecnocultural fundamental e sine qua non - um sprit du temps - válida (podese dizer, pretensamente) para todos os viventes (seja para sentirem e pensarem o mundo, seja para serem e agirem nele), desde, pelo menos, meados do século $\mathrm{XX}$ e, mais fortemente, a partir da década de 1970. (Trivinho, 2012: 14).

O modo de existência na condição glocal, dessa forma, não é específica para lugares, mas uma realidade planetária dos corpos que estão conectados em rede. Esses corpos glocais ou corpos glocalizados estão em uma situação específica onde a própria existência e a realidade cotidiana se hibridiza, como uma terceira realidade; de forma análoga, entende-se a transformação da noção dualista de global e local em detrimento de uma terceira condição, não mais local nem global, mas glocal.

Ainda, merece atenção o entendimento de como as informações em condição glocal são negociadas com os corpos glocais. Para isso, considera-se uma perspectiva de co-evolução entre 
corpo e ambiente, entre cognição e cultura que, para Greiner (2005: 103), é uma proposta que já vem sendo discutida há pelo menos trinta anos. Essa proposição de coevolução

Rompe com a ideia de influência, na medida em que entende a relação entre corpo e ambiente em movimentos de mão dupla. Ou seja, não é a cultura que influencia o corpo ou o corpo que influencia a cultura. Trata-se de uma espécie de "contaminação" simultânea entre dois sistemas sígnicos onde ambos trocam informações de modo a evoluir em processo, juntos. (Greiner, 2005: 102 103).

Dessa forma, o corpo é entendido como processo. Nas palavras de Greiner (2005: 122), "o corpo muda de estado cada vez que percebe o mundo". Afasta-se diametralmente dessa noção de corpo o entendimento de que as informações “entram” em contato, são processadas e, depois "devolvidas" ao ambiente. Katz e Greiner (2005: 130) explicam melhor essa proposição:

Capturadas pelo nosso processo perceptivo, que as reconstrói com as perdas habituais a qualquer processo de transmissão, tais informações passam a fazer parte do corpo de uma maneira bastante singular: são transformadas em corpo. Algumas informações do mundo são selecionadas para se organizar na forma de corpo - processo sempre condicionado pelo entendimento de que o corpo não é um recipiente, mas sim aquilo que se apronta nesse processo co-evolutivo de trocas com o ambiente. E como o fluxo não estanca, o corpo vive no estado do semprepresente, o que impede a noção de corpo recipiente.

Essa situação do corpo que se constrói com as informações, resolve uma questão de entendimento crucial para o que se propõe nesse estudo: o corpo produz informações, processa informações e é, em si mesmo, informação. O corpo, assim, é como uma mídia que não "abriga" as informações; elas entram em negociação ou se cruzam com as informações que o corpo já possui. A analogia de corpo com mídia, então, difere e se distancia de corpo como recipiente de informações ou de mídia como um mero veículo de transmissão de informações.

Assim, a noção de corpomídia lida com o corpo como resultante da negociação ou cruzamento de todas as informações que chegam com as que já estão no corpo. Ele constrói-se, coevolutivamente, em interação com o 
ambiente. Sinteticamente, "a mídia à qual o corpomídia se refere diz respeito ao processo evolutivo de selecionar informações que vão constituindo o corpo. A informação se transmite em processo de contaminação" (Katz e Greiner, 2005: 131). É interessante, nesse ponto, perceber a construção de novos vocabulários - como "corpomídia" - para dar conta de novas percepções sobre o mundo e a existência. Greiner (2005: 55) explica que

[…] as metáforas do corpo vão sendo construídas e, ao mesmo tempo, abrem a possibilidade de novos modos de organização do ambiente a seu redor, na medida em que se transformam em metáforas do mundo [...]. Este fluxo incessante constrói novos vocabulários que são muito mais que nomes vagando pelo mundo. Este "novo vocabulário" reflete modos de organização dos pensamentos que organizam as ações corpóreas e o mundo.

Sob o viés da teoria corpomídia, vale se ater sobre o processo de transmissão da informação. É um importante aspecto para explicar como uma ideia/discurso encontra ressonância em um ambiente. A operação de transmissão de informações dá-se graças a uma unidade de transmissão cultural: o meme.

Exemplos de memes são melodias, idéias, "slogans", modas do vestuário, maneiras de fazer potes ou de construir arcos. Da mesma forma como os genes se propagam no "fundo" pulando de corpo para corpo através dos espermatozóides ou dos óvulos, da mesma maneira os memes propagam-se no "fundo" de memes pulando de cérebro para cérebro por meio de um processo que pode ser chamado, no sentido amplo, de imitação. Se um cientista ouve ou lê uma idéia boa ele a transmite a seus colegas e alunos, ele a menciona em seus artigos e conferências. Se a idéia pegar, pode-se dizer que ela se propaga, a si própria, espalhando-se de cérebro a cérebro. (Dawkins, 2001: 214).

A cultura evolui - e a afirmação implica que os memes estão sujeitos a contínua transformação e mistura: isto se dá porque o mecanismo de transmissão de informação, como uma contaminação, dáse quando um meme encontra um ambiente propício para que ela aconteça. "Se o meme for uma ideia científica, sua difusão dependerá do quão aceitável ela é para a população de cientistas" (Dawkins, 
2001: 216). Nesse sentido, os memes podem ser entendidos como replicadores, mas não atuam replicando conteúdos de forma fidedigna. Por exemplo, "cada vez que um cientista ouve uma idéia $\mathrm{e}$ transmite-a a outra pessoa ele provavelmente muda-a bastante [...]. Os memes estão sendo transmitidos a você sob forma adulterada" (Dawkins, 2001: 216).

Assim, entende-se que as informações quando "chegam" em um corpomídia, ao serem cruzadas com as informações que "já estão no corpo", se tornam corpo. Nesse processo, a informação que chega sofre mutação, desde que há sempre o cruzamento/negociação com as informações "que estão dentro". Dessa forma, há uma taxa de transformação nas informações (discursos, ideias) que são replicadas em um ambiente, quando "pulam” de um cérebro para outro. Os discursos podem funcionar como ideias que se propagam "memeticamente". Eles são práticas articulatórias estruturadas dentro uma gama de instituições, de rituais e práticas, da mesma forma como acontecem nos chamados aparelhos ideológicos de Althusser ou nos dispositivos de Foucault e Agamben (Prado, 2013: 98).
Propõe-se que o corpomídia é uma realidade viva, em perpétua transformação desde que ele está em condição de interação com o ambiente, também outra realidade viva, em fluxo constante de informações: sujeito/corpomídia não passivo, mas através da força das convocativas mediáticas - entendidas como dispositivos de poder - constrói seu entendimento sobre o mundo, "aprontando" ou construindo seu corpo; negocia as informações que lhe constituem corpo e que agem sob sucessivas camadas de transformação.

As convocativas mediáticas constituem-se como elementos fundamentais para impelir no corpomídia o desejo de consumo das informações que se caracterizam como afins ao seu modo de perceber o mundo. Por outro lado, impelem também a repulsa por informações ou dados que não encontram ressonância com ele.

O corpomídia glocalizado lida com cruzamentos de informações de forma efetiva, onde a conexão mundial de informações que reverberam não obedecem mais a ambientes exclusivamente físicos, mas também na esfera digital. Por isso, é importante considerar como os corpomídias glocalizados ressoam as informações na internet, desde quando os 
posicionamentos dos sujeitos em interação cibernética hoje são, inclusive, sujeitos a processos e punições judiciais, através de varreduras pela justiça de IPs (números de identificação de hardware), o que denota que o que se "diz" ou se "posta" na internet, como uma opinião pessoal, quando vai de encontro a lei, é passível de punição, pois o sujeito não é apenas uma "sombra" digital ou um avatar, mas é entendido como um sujeito real e de fato. Isso vale para salientar que certas opiniões/discursos a respeito de acontecimentos, mesmo quando não agradem, não podem ser vistos na internet sob meras palavras livres de responsabilidade social e, acima de tudo, legal.

Diante do exposto, consideram-se algumas reverberações mediáticas geradas sobre a Parada Gay de São Paulo, ocorrida no mês de maio de 2015, em especial, sobre a performance da atriz transexual Viviany Beleboni, que em um ato performático, carregou uma cruz em um carro, no desfile na Avenida Paulista.

\section{A Avenida Paulista e a territorialidade}

\section{LGBT}

O território deve ser concebido enquanto um campo de forças ou uma rede de relações sociais. Sendo assim, presume- se que vários tipos distintos de organização espaço-temporais podem ser percebidos em um mesmo recorte espacial. Não há a necessidade de uma base material fixa com base em espaços concretos. Conforme Souza (2006), podem ser constituídos e dissipados de forma rápida. Apesar da permanência de um substrato material, a territorialidade pode se estabelecer de forma periódica, atendendo às necessidades de posicionamento de determinado grupo social face a uma arena de poder. Essas territorialidades flexíveis se transformaram em fato recorrente nas grandes metrópoles mundiais.

No caso da Avenida Paulista, no centro nervoso de São Paulo, maior cidade do Brasil, o território cotidianamente ocupado pelos trabalhadores, executivos, consumidores e moradores, preocupados em fazer os "negócios" fluírem na capital paulista, cede espaço para uma territorialidade flexível e sazonal na época da Parada Gay de São Paulo. Este substrato material comumente ocupado por pessoas de vida "comum", se transforma em território LGBT anualmente.

De acordo com Trindade (2011: 77), uma concentração na Praça Roosevelt, em São Paulo, ocorrida em 28 de junho de 1996, por iniciativa do 
jornalista Paulo Giacomini, deu origem à chamada Parada Gay de São Paulo. Giacomini, via jornal Folha de São Paulo, convocou homossexuais, aludindo às revoltas de Stonewall, nos Estados Unidos.

No dia marcado para a concentração, na Praça Roosevelt estavam presentes apenas alguns atuantes militantes, algumas drags, conhecidas por suas performances nas boates gays da cidade e outras personalidades da cena gay, além, vale dizer, dos punks que se solidarizavam com as reivindicações dos gays e lésbicas. Sobre a (pequena) quantidade de pessoas que compareceram ao evento, um jornalista de São Paulo sugeria que o homossexual brasileiro preferia $\mathrm{o}$ anonimato de seus armários à exposição pública de sua orientação sexual. (Trindade, 2011: 77).

Apesar de uma aparente resistência inicial da comunidade gay de São Paulo, o evento encontra poder geopolítico, ao desembocar na Avenida Paulista como foco para o evento, logo no ano seguinte, em sua segunda edição, carregando o nome de Parada do Orgulho GLT (gays, lésbicas e travestis) ou Parada do Orgulho Gay de São Paulo.
Dessa vez, não estavam apenas os fundadores do movimento e os grupos punks. Misturados à multidão estavam agora os anarquistas, militantes da CUT e de alguns partidos políticos como PT e PSTU, personalidades do meio artístico, da noite e da moda, além de muitos outros desconhecidos que, de acordo com cálculos da Polícia Militar, totalizaram 3,5 mil pessoas. (Trindade, 2011: 80).

Entretanto, diferente dos cálculos da Polícia Militar, os organizadores do evento contabilizaram cerca de 6000 (seis mil) participantes na parada de 28 de junho de 1997. Esses números ajudaram a consolidar a parada gay como um evento de visibilidade nacional, sendo esperado anualmente por milhares de pessoas de São Paulo e estados vizinhos, o que demandou uma estrutura mais organizada e complexa. Dessa forma, em 1999, foi criada a Associação da Parada do Orgulho GLBT (gays, lésbicas, bissexuais e travestis). No ano de 1998, os organizadores estimavam 14.000 pessoas no evento, mas cerca de 20.000 pessoas compareceram. Alianças importantes entre os organizadores e militantes artistas e intelectuais deram a parada a abrangência e importância política necessária que vinham à tiracolo do 
grande número de público presente na manifestação. Em 1999, a parada ganhou cunho de semana cultural, com eventos acontecendo durante toda a semana que precedia o desfile (Trindade, 2011: 86).

Mesmo com a grande visibilidade que a parada atingia a cada ano, replicando memes sobre a necessidade da luta contra a homofobia, os crimes de ódio ainda eram registrados em grande número. Trindade (2011: 88) cita uma reportagem do jornal Folha de São Paulo, no Caderno Cotidiano, de 15 de fevereiro de 2001, onde lê-se que apenas com base em notícias da imprensa, 130 homossexuais haviam sido assassinados no ano de 2000. Assim, nos anos subsequentes, parecia ser notório que a política de visibilidade do evento pudesse dar mais qualidade na vida dos homossexuais da cidade. Com uma história de muitos sucessos e avanços, principalmente no sentido de garantia de espaços geopolíticos para os homossexuais na cidade de São Paulo, a parada parece de fato ter ainda $\mathrm{o}$ aspecto político $\mathrm{da}$ visibilidade um dos pontos principais de sua estratégia de permanência evolutiva, onde pronuncia com efetividade seu poder como meme.

Concorda-se com Trindade (2011: 92) quando ele explica que
Hoje, São Paulo possui a maior Parada Gay do mundo e o Brasil é um dos países que conta com o maior número de cidades que realizam esse tipo de manifestação. O tímido movimento passou a ser uma referência mundial, entrando na rota do turismo gay mundial e colocando São Paulo entre as cidades mais gays do mundo.

Do tímido início para os anos atuais percebe-se uma considerável modificação o ato, representada pela grande adesão da comunidade gay. Não somente gays moradores de São Paulo se territorializam na Avenida Paulista no dia do evento. Gays oriundos de diversos estados brasileiros e de outras partes do mundo, comparecem a São Paulo, transformando a Parada Gay paulistana em um evento de visibilidade nacional e internacional.

Os fatos ocorridos durante a marcha ganham repercussão na mídia, seja impressa, televisiva ou através das redes sociais. Notícias sobre os fatos ocorridos durante a marcha rodam o mundo. No evento de 2015 a performance da atriz e transexual Viviany Beleboni ganhou grande projeção na mídia nacional e internacional. 


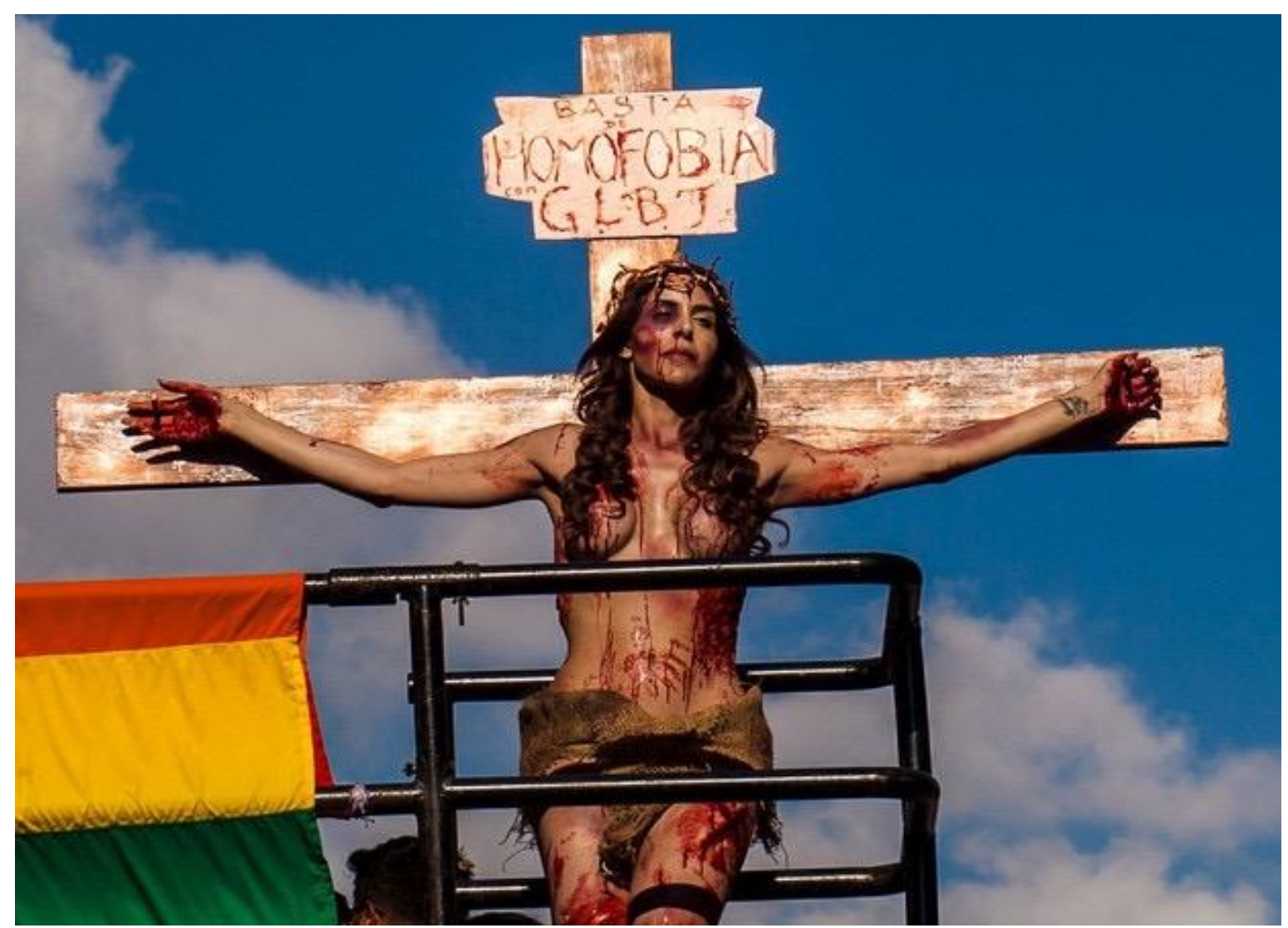

Viviany Beleboni na Parada Gay de São Paulo, 2015.

Fonte: Registro fotográfico por Joao Castellano para a Reuteurs, extraído de <http://s2.glbimg.com/mN7Gz1PfFdg8zlwbBToeAx8UYk=/620x465/s.glbimg.com/jo/g1/f/original/2015/06/07/2015-0607t192043z_15110779.jpg >. Acesso em 29 de jun. 2015.

Beleboni participou da Parada Gay exibindo seu corpo seminu, de braços abertos preso a uma cruz, sobre um carro que compunha os elementos da parada paulistana. Sobre a sua cabeça, no alto da cruz, jazia uma inscrição: "Basta de Homofobia GLBT”. Em sua cabeça, prendendo seus longos cabelos, se via uma coroa de espinhos, tal qual a que é representada sobre a cabeça de Cristo crucificado. Seu ventre estava coberto por um tecido rústico. $\mathrm{O}$ corpo à mostra, além das chagas referentes ao sinal da crucificação, apresentava marcas de agressão no rosto e manchas de sangue espalhadas pelo corpo, sobretudo em seu tronco. Em um contexto glocal, é fácil entender como esta imagem circulou o planeta. Tendo sido registrada pelas "lentes" de Joao Castellano (2015), fotógrafo de uma das maiores agências de notícias do mundo, a Reuters. A imagem despertou os mais diferentes tipos de manifestação, de diversos segmentos da sociedade.

Ao ser indagada sobre a real intenção da sua performance, Beleboni respondeu que representava a dor de todas 
as travestis, e, em uma atitude política, que seu flagelo representava todos os gays que são crucificados cotidianamente em nossa sociedade. Sua performance e seu discurso político teve, como consequência, não somente uma forte discussão a respeito da apropriação de uma imagem cristã por parte de uma transexual, mas, inclusive, até ameaças de morte, segundo a própria atriz (Folha do Povo Notícias, 2015). Ainda, segundo Beleboni, sua intenção nunca foi a de atacar o cristianismo; ela apenas se apropriou de um símbolo que representa sofrimento e dor, para representar as vítimas de homofobia da comunidade LGBT no Brasil (Portal Gay1, 2015). O tratamento político do ato fica bastante claro em seu discurso verbal, quando ela afirma que "Eu vejo a parada como um protesto, e não como uma festa”. E reage às críticas à alusão do uso da imagem de Cristo, como um preconceito de gênero, quando questiona: "Tudo bem encenar a Paixão de Cristo, mas quando é um travesti não pode, né?” (apud Castro, 2015).

Do outro lado do discurso de Beleboni, posicionou-se o deputado federal Marcos Feliciano, liderando um cristianismo de base fundamentalista, que cerceia o direito civil daquele que discorda do que ele prega (Dantas, 2015). Igualmente, o pastor Silas Malafaia fez coro ao discurso de Feliciano com reações contrárias mais contundentes (Moraes, 2015). Para corpomídias cujas constituições se baseiam em (in)formações religiosas, é mais cômodo reduzir o ato político da atriz transexual a uma agressão ao cristianismo. Apesar desses representantes de uma opinião contrária tanto à manifestação de Beleboni quanto aos próprios direitos LGBTs e à Parada Gay, essa "cruzada cristã” “[ [...] liderada por pastores como Malafaia, o deputado Marco Feliciano (PSC-SP) e o agora todo poderoso deputado presidente Eduardo Cunha (PMDB-RJ) [...]”, aparenta ser, no entanto, uma espécie atirada de “[ $[\ldots]$ cortina de fumaça sobre outros interesses escusos jogados no Congresso" (Moraes, 2015).

Usando as mídias, Feliciano postou, em sua página da rede social Facebook, palavras que descredenciavam o ato, classificando o ato político da atriz como blasfêmia ou falta de respeito, induzindo manifestações de seus seguidores. Tal atitude vem corroborar com a criação de um universo onde as mortes e agressões sofridas pela comunidade LGBT no Brasil são tratadas com desimportância ou pouco significativas, representando um completo cerceamento dos direitos humanos da comunidade LGBT brasileira. Afinal, 
"Jesus morreu por todos e foi humilhado, motivo de chacotas, agredido e morto, que é o que vem acontecendo diariamente com GLBTs, por não termos leis", rebate Viviane (apud Castro, 2015).

A situação política brasileira encontra-se em um cenário de difícil definição, porquanto os discursos advindos de orientações políticas, em uma pátria supostamente laica, vêm atados à discursos religiosos. Infelizmente, essa situação não é específica do contexto brasileiro. Notadamente,

A reivindicação da religião como elemento constitutivo da vida pública é um fenômeno que tem vindo a ganhar relevância na últimas décadas em todo o mundo. Trata-se de um fenômeno multifacetado, tanto no que respeita às denominações envolvidas como no tocante às orientações políticas e culturais. Mas a sua presença é marcante em todo o mundo e as redes que a alimentam são transnacionais, o que nos permite nomeá-la como fenômeno global. (SANTOS, 2014, p. 31).

Crer, então, que em um país supostamente laico as instâncias dos discursos culturais/religiosos sejam eximidas, parece não encontrar lugar, quando há uma atuação/militância de valores por uma parte da população, auxiliada pela rede midiática. Entenda-se esses valores, aqui, como valores cristãos (ou que se propõem a ser, seja lá qual for o entendimento que se faça de cristianismo). Na situação brasileira, não há uma religião cristã apenas, e as convocativas do discurso religioso que beira o fundamentalismo já deixou marcas e sequelas em um passado não muito distante, vale rememorar a Marcha $d a$ Família com Deus pela Liberdade, ocorrida em São Paulo em 19 de março de 1964, que reuniu estimadamente de 500 a 800 mil pessoas.

Abertamente, o discurso da Marcha era um discurso político contra João Goulart (1961 - 1964), então presidente do Brasil, com o apoio do governador paulista, Ademar de Barros, que apoiou o Golpe de Estado alguns dias depois. O discurso político estava claramente investido de uma espécie de autorização divina, na qual a "liberdade" e os valores da família cristã poderiam salvar o Brasil contra os "comunistas".

Curiosamente, a Marcha se deu em São Paulo e, como herança desse movimento, memes do pensamento dos valores da família cristã ainda se mesclam com o discurso político e refletem-se nas urnas paulistas na atualidade, com a eleição de candidatos que representam um pensamento de direita que nega a 
diversidade e as manifestações sociais que porventura desacatem ou ponham em xeque os tais valores cristãos, em detrimento da livre expressão e da liberdade sexual. Esses memes reescalonam para um patamar nacional uma postura que garante a sobrevivência desse tipo de oposição às orientações sexuais ou quaisquer discursos imagéticos, falados ou escritos que vão de encontro aos valores ditos cristãos.

Desta forma, não há separação de um discurso religioso e político como instâncias duais: são complementares e oportunos, quando realizam, com o biopoder de que lhes é assegurado, regulações e restrições que vitimizam o corpomídia que expressa, em si mesmo, o diferente ou o fora do padrão como perigoso e contra-hegemônico. O fundamentalismo cristão brasileiro encontra sua força na história do país, e reverbera nos três poderes, deixando marcas no seu território.

O contexto brasileiro, nesse viés, assemelha-se ao que Santos (2014, p. 38) vai designar como "teologias políticas". Ele designa o termo como “ $[\ldots]$ os diferentes modos de conceber a intervenção da religião, como mensagem divina, na organização social e política da sociedade”. Como já foi dito, não há no Brasil apenas uma religião cristã. Mas parte-se aqui de uma compreensão do termo "religião", no sentido proposto por Santos (2014), de uma forma generalizante, que abrange um pensamento religioso, onde diferentes religiões têm, supostamente, um vetor central, o discurso identitário do cristianismo.

Como processo identitário, é interessante perceber a atuação das religiões cristãs, quando o sujeito incluído exclui qualquer outra possibilidade de culto divino: vale lembrar que o discurso identitário é excludente, dicotômico e não conexo com a noção de complexidade. Conectado com o discurso identitário cristão, o sujeito alça-se à posição de defensor de um discurso com sanção divina, onde o certo e o errado estão atrelados ao que pressupõe o teor bíblico. É um discurso que organiza a sociedade brasileira, apesar de legalmente laica.

\section{Considerações Finais}

As informações ecoam memeticamente, sem controle, passando de cérebro para cérebro, como um processo viral de contaminação. Esse processo de contaminação memética se dá em fluxo contínuo, e, como uma contaminação viral, o corpo é foco central e vetor principal do processo: as informações são negociadas com o corpo. 
Quando as informações que "chegam” com as “que já estão" no corpo são cruzadas, é que o corpomídia constrói a informação EM corpo. Nesse viés, pode-se dizer que não há melhoria (desenvolvimento) ou piora na qualidade das informações: há, certamente, transformação (evolução), desde que informações em fluxo exigem cruzamento com as informações do corpo para serem ressonadas no ambiente.

Assim, adotou-se uma perspectiva co-evolucionista, em que o corpo e o ambiente são entidades que evoluem em conjunto: entidades não estanques, onde natureza e cultura são vistas de formas complementares e onde uma exerce atuação na outra, e vice-versa. Em outras palavras, a perspectiva é a de que o corpo se "apronta" em relação direta com o ambiente, em trocas incessantes de informações. Essa visão proporciona o entendimento de que informações que vão contra o preconceito precisam ser ressonadas no ambiente, a fim de que sejam replicadas e possam exercer possível transformação política nos corpomídias glocalizados que lidam com o cruzamento dessas informações.

A performance de Beleboni na Parada Gay de São Paulo, em sua edição de 2015, ganhou repercussão mediática. Imagens e discursos do desfile performático da atriz transexual na parada foram replicadas, e, em um processo de memetização, a informação foi negociada, inclusive, com corpomídias glocais que não assimilaram ou relativizaram aquele discurso contextualmente, sem o esforço de considerar a territorialidade flexível onde se deu o evento e a característica histórico-política do movimento gay a nível mundial que o evento carrega.

Apesar das tentativas de explicar que a sua apresentação teve unicamente um caráter de protesto contra a homofobia no Brasil, Beleboni soçobrou em seus esforços, no sentido de que uma performance publicamente exibida (informação difundida/veiculada) não tem poder de controlar a forma como ela será reverberada ou "recebida". Em outras palavras, uma informação ressonada em um ambiente não pode ser direcionada, desde que os corpomídias que negociam/cruzam essa informação com as que possuem, já a transformam. Assim, diferentes percepções são produzidas quando da ressonância de um discurso (imagético, verbal, entre outros), especialmente, dado o caráter ambíguo intrínseco que qualquer trabalho artístico apresenta, mesmo quando em se tratando de uma arte ativista.

Apesar da desaprovação de uma parte da população que se sentiu ofendida ou não representada com a performance 
de Beleboni, a importância do ato residiu no poder do meme: a visibilidade de uma artista ativista que denunciou a homofobia, em uma Parada Gay, talvez não tivesse encontrado reações, caso seu corpomídia não resolvesse a informação da identidade transexual em sua configuração. E, neste viés, encontra a moral co-evolutiva: sua existência e discurso identitário travestido em corpomídia, reverbera essa informação. Definitivamente, seu corpomídia é, em si mesmo, a materialidade do discurso de resistência contra a hegemonia fundamentalista cristã do preconceito.

\section{NOTAS}

${ }^{1}$ Professor Adjunto/ DGH - IGEOG - UERJ. niltonabranches07@yahoo.com.br

${ }^{2}$ Professor Assistente/ DAC - CCTA - UFPB

Doutorando em Comunicação e Semiótica/ PUC-SP. arthur_marques@yahoo.com.br

3 "The local may have to be understood as somehow interdependent with the global; globalization may always involve localization. Thus, we are given the neologism, 'glocalization". (BAUCHSPIES at al., 2006: 100).

4 O termo 'mediático(a)' é assim grafado por autores como Trivinho (2012) e Prado (2013). A grafia 'midiático(a)' é usada por outros autores como Muniz Sodré (As estratégias sensíveis: afeto, mídia e política. Petrópolis, RJ: Vozes, 2006). Os termos são sinônimos, mas a grafia 'mediática' é aqui adotada pela aproximação com os estudos de Trivinho (2012).

\section{REFERÊNCIAS BIBLIOGRÁFICAS}

BAUCHPIES, Wenda K. at al. (2006), Science, technology and society. A sociological approach. Malden/USA, Oxford/UK, Carlton/Australia: Blackwell Publishing.

BECKER, Bertha (1983), O uso politico do território: questões a partir de uma visão do terceiro mundo. In: Becker, B; Haesbarth, R; Silveira, C (org.), Abordagens políticas $d a$ espacialidade, Rio de Janeiro, UFRJ.

BRITO-HENRIQUES, Emanuel (2009), Fausto entre nós. Geografias pós-humanas. In: Azevedo, Ana Francisca; Pimenta, José; Sarmento, João (org). Geografias do corpo. Ensaios de Geografia Cultural, Porto, Livraria Figueirinhas, 81-98.

CASTRO, Sérgio (2015), "O protesto da modelo transexual Viviany Beleboni, 26, que se vestiu como Jesus Cristo e encenou a própria crucificação durante a $19^{\mathrm{a}}$ Parada do Orgulho LGBT (Lésbicas, Gays, Bissexuais, Travestis e Transexuais) de São Paulo, neste domingo (7), lhe rendeu inúmeras críticas nas redes sociais e, segundo ela, ligações com ameaças de morte". Página consultada em 29.06.2015,

http://noticias.uol.com.br/cotidiano/ultimasnoticias/2015/06/08/transexual-crucificada-naparada-gay-de-sp-diz-ter-sido-ameacada-demorte.htm.

DANTAS, Carolina (2015), “'Representei a dor que sentimos', diz transexual 'crucificada' na Parada Gay. Xingada na web, Viviany Beleboni diz que ato foi protesto anti-homofobia. Deputado Federal Marco Feliciano postou a foto com mensagem de repúdio”. Página consultada em 29.06.2015, em http://g1.globo.com/saopaulo/noticia/2015/06/representei-dor-quesentimos-diz-transexual-crucificada-na-paradagay.html.

DAWKINS, Richard (2001), O gene egoísta. Belo Horizonte: Ed. Itatiaia.

FOLHA DO POVO NOTÍCIAS (2015), “Transexual 'crucificado' na parada gay é ameaçado de morte após causar revolta nas redes sociais”. Página consultada a 29.06.2015, em https://www.youtube.com/watch?v=uuKMRecZy Os.

GREINER, Christine (2005), O corpo. Pistas para estudos indisciplinares. $2^{\text {a }}$. Ed. São Paulo: Annablume. 
CASTEllanO, Joao (2015), “Manifestação contra a homofobia na $19^{a}$ Parada do Orgulho LGBT na Avenida Paulista, neste domingo (7)". Tipo: JPEG. Tamanho: 69.853 bytes. Dimensões: $620 \times 465$. Espectro de cores: RGB. Consultada a 29.06.2015, em http://s2.glbimg.com/$\mathrm{mN} 7 \mathrm{Gz} 1 \mathrm{PfF} d g 8 z l w b B T 0 e A x 8 \mathrm{UYk}=/ 620 \mathrm{x} 465 / \mathrm{s}$. glbimg.com/jo/g1/f/original/2015/06/07/201506-07t192043z_15110779.jpg.

KATZ, Helena; GREINER, Christine (2005), "Por uma teoria do corpomídia”, in Greiner, Christine. $O$ corpo. Pistas para estudos indisciplinares. $2^{\text {a }}$ Ed. São Paulo: Annablume, 125-133.

MORAES, Maurício (2015), "Vão ter de engolir os LGBT”. Página consultada a 30.06.2015, em http://www.cartacapital.com.br/sociedade/vaoter-de-engolir-os-lgbt-1841.html.

PINHEIRO, Amálio (2009), "O texto em expansão. Crônica jornalística e paisagem cultural na América Latina”, in Pinheiro, Amálio (org.), O meio é a mestiçagem. São Paulo: Estação das Letras e Cores, 17-30.

PORTAL GAY1 (2015), "Em vídeo, Viviany Beleboni fala sobre ato anti-homofobia na Parada LGBT de SP”. Página consultada a 29.06.2015, em
https://www.youtube.com/watch?v=085fTKnbG oA.

PRADO, José Luiz Aidar (2013), Convocações biopolíticas dos dispositivos comunicacionais. São Paulo: EDUC: FAPESP.

SAQUET, Marco Aurélio (2007), As abordagens e concepções do território. São Paulo: Expressão Popular

SOUZA, Marcelo José Lopes (2006), “O território: sobre espaço e poder, autonomia e desenvolvimento", in Castro, Iná Elias at al. (orgs.), Geografia. Conceitos e temas. 8a. Ed. Rio de Janeiro: Bertrand Brasil. 77-116.

TRINDADE, Ronaldo (2011), “O mito da multidão: uma breve história da parada gay de São Paulo", Revista Gênero, 11 (2), 73-97. Consultado a 29.06.2015 em http://www.revistagenero.uff.br/index.php/revist agenero/article/view/332.

TRIVINHO, Eugênio (2012). Glocal: Visibilidade mediática, imaginário bunker e existência em tempo real. São Paulo: Annablume, 2012. 


\section{RELIGION, GENDER AND TERRITORY: MEDIA SPEECHES ABOUT SÃO PAULO GAY PARADE}

ABSTRACT: tHE GAY PARADE IN SAO PAULO IS ChARACTERIZED AS A BRAZILIAN GLBT POLLTICAL ACTIVITY SPACE, BRINGING TOGETHER PARTICIPANTS FROM ALL PARTS OF THE COUNTRY, GENERATING MEDIA VISIBILITY AT WORLD LEVEL. THIS PAPER AIMS tO DISCUSS tHE PERFORMANCE OF THE TRANSSEXUAL ACTRESS VIVIANY BELEBONI DURING EVENT EDITING JUNE 28, 2015 AND ITS SUBSEQUENT REVERBERATION IN THE MEDIA. IT BASES thIS DISCUSSION CORPOMIDIA THEORY OF KATZ AND GREINER (2005) AND THE MEME THEORY OF DAWKINS (200I), TO RELATE THE RESONANCE OF INFORMATION AND THEIR PERCEPTION BY THE BODY. THE RELATIONSHIP OF THE TWO THEORIES POINT TO A POLITICAL ASPECT: THE TRANSFORMATION OF INFORMATION INTO BODY, FROM WHEN IT IS UNDERSTOOD AS MEDIA AND SPEECH. IT IS NOTICED THAT THE TRANSSEXUAL CORPOMIDIA IS IN ITSELF AN IMAGISTIC DISCOURSE OF RESISTANCE AGAINST HEGEMONIC ACTIONS OF HOMOPHOBIC CHARACTER, BACKED BY THE ABSENCE OF SPECIFIC LEGISLATION TO REGULATE THESE ACTS OF VIOLENCE AS A CRIME.

KEYWORDS: HOMOPHOBIA. TRANSSEXUAL. CORPOMÍDIA. MEME. GAY PARADE.

RELIGIÓN, GÉNERO Y TERRITORIO: DISCURSOS MIDIÁtICOS DEL PARADA GAY DE SÃO PAULO

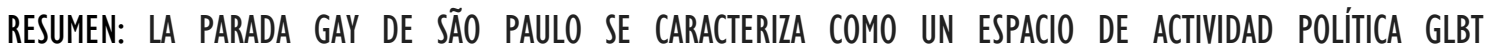

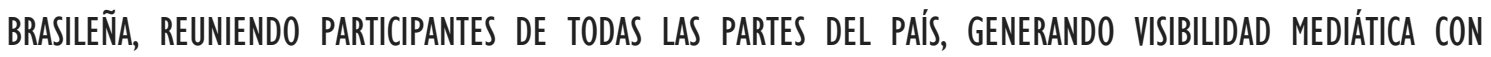
REPERCUSIÓN MUNDIAL. EL PRESENTE TRABAJO TIENE COMO OBJETIVO DISCUTIR LA ACTUACIÓN DE LA ACTRIZ tRANSEXUAL VIVIANY BelebONI DURANTE LA EDICIÓN DEL EVENTO DEL 28 DE JUNIO DE 2015 Y SU CONSECUENTE REVERBERACIÓN EN EL ESPACIO MEdIÁtICO. LA TEORÍA dEL CORPOMÍDIA DE KATZ Y GREINER (2005) Y LA TEORÍA DEL MEME DE DAWKINS (200I), FUNDAMENTA ESTA DISCUSIÓN SOBRE LA RESONANCIA DE LA INFORMACIÓN Y SU 
PERCEPCIÓN POR EL CUERPO. LA RELACIÓN DE LAS DOS TEORÍAS APUNTA A UN ASPECTO POLÍTICO: LA TRANSFORMACIÓN DE LA INFORMACIÓN EN CUERPO, DESDE CUANDO ES ENTENDIDO COMO MEDIOS Y DISCURSO. SE PERCIBE QUE LA CORPULENCIA tRANSEXUAL ES UN DISCURSO IMAGÉtICO DE RESISTENCIA CONTRA ACCIONES HEGEMÓNICAS DE CARÁCTER HOMOFÓBICO, RESPALDADAS POR LA AUSENCIA DE LEGISLACIÓN ESPECÍFICA QUE REGULEN ESOS ACTOS DE VIOLENCIAS COMO CRIMEN.

PALABRAS CLAVE: RELIGIÓN. GÉNERO. DE LA COMUNICACIÓN. MEME. TERRITORIO. 